Original article

\title{
A protein-free diet alters small intestinal architecture and digestive enzyme activities in rats
}

\author{
Carlos Alexander Montoya ${ }^{\mathrm{a}}$, Pascal LeTERME ${ }^{\mathrm{a}, \mathrm{b}}$, Jean-Paul LALLES $^{\mathrm{c} *}$ \\ a Universidad Nacional de Colombia, Departamento de Produccion Animal, Carrera 32 Chapinero, \\ Palmira (Valle), Colombia \\ b Present address : Prairie Swine Centre, 2105 8th Street East, Saskatoon, 57H 5N9, Canada \\ ${ }^{c}$ INRA-Agrocampus Rennes, UMR SENAH, Domaine de la Prise, 35590 Saint-Gilles, France
}

(Received 10 January 2005; accepted 22 July 2005)

\begin{abstract}
The consequences of feeding a protein-free (PF) diet, as compared to casein, on gut characteristics were studied in slightly energy-restricted rats fed similar amounts of feed for $10 \mathrm{~d}$. The weight and $\mathrm{pH}$ of fresh digesta in the stomach were lower $(P=0.045$ and $P=0.016)$. However, the weight of fresh digesta in the other segments and gut tissue weight were not significantly affected by the diet $(P>0.05)$. Small intestinal crypt depth, width and area were reduced by 13,23 and $37 \%$, respectively $(P=0.011, P=0.004$ and $P=0.001)$, and villus width tended to be smaller $(P=0.057)$, with the PF diet. Villus height to crypt depth ratio was also lower with the PF diet in the duodenum and ileum, respectively $(P<0.05)$. Finally, the specific activities of alkaline phosphatase and aminopeptidase $\mathrm{N}$ were reduced by 36 to $38 \%$ at different sites of the small intestine in the rats fed the PF diet $(P<0.05)$. In conclusion, chronic consumption of a protein-free diet altered the intestinal villus-crypt architecture and enzyme activities in rats.
\end{abstract}

rat / protein-free diet / intestine / villus-crypt architecture / enzyme

\section{INTRODUCTION}

Feeding a protein-free (PF) diet to animals is common practice in digestion experiments in order to determine the socalled basal endogenous protein losses and, therefore, the true digestibility of dietary protein $[1,2]$. This has been questioned since it is non physiological [3] and it affects protein synthesis rate of the whole body and the amount of protein entering the gut [4]. In baby calves, small intestinal villus-crypt architecture and digestive enzyme activities of the mucosa were drastically reduced with a PF diet [5]. However, literature data in rats are scarce, despite the numerous studies on gut endogenous protein losses in this animal species [6-8]. Chronic malnutrition and starvation in rats impair the gross anatomy of the gut, intestinal epithelial crypt cell proliferation (CCPR) and digestive enzyme activities [9-11].

Owing to the lack of specific data, we investigated the impact of a PF diet on gut weight characteristics and small intestinal morphology and mucosal enzyme activities

\footnotetext{
* Corresponding author: jean-paul.lalles@ @ennes.inra.fr
} 
Table I. Composition of the experimental diets.

\begin{tabular}{lcc}
\hline & \multicolumn{2}{c}{ Diet $^{1}$} \\
\hline & Casein & PF \\
Ingredients $\left(\mathrm{g} \cdot \mathrm{kg}^{-1}\right)$ & 118 & 0 \\
Casein $^{2}$ & 582 & 700 \\
Starch & 100 & 100 \\
Others $^{3}$ & 10 & 10 \\
Vitamin-trace elements $^{4}$ & & \\
Analysis $\left(\mathrm{g}\right.$ or kcal $\left.\cdot \mathrm{kg}^{-1} \mathrm{DM}\right)$ & 109 & 9 \\
Protein $(\mathrm{N} \times 6.25)$ & 65 & 62 \\
Ether extract & 71 & 64 \\
Ash & 63 & 68 \\
NDF & 3909 & 3967 \\
Energy & &
\end{tabular}

${ }^{1}$ PF: protein-free diet.

${ }^{2}$ Casein was supplemented with $30 \mathrm{~g}$ DL-methionine per $\mathrm{kg}$ dry matter.

3 Others $\left(\mathrm{g} \cdot \mathrm{kg}^{-1}\right):$ sucrose 100 , ground rice hulls 80 , vegetable oil 60 , sodium chloride 10 , calcium carbonate 15 and calcium phosphate 25 .

${ }^{4}$ Mineral and vitamin mixture supplied per $\mathrm{kg}$ of diet: 25000 IU vitamin A; 5000 IU vitamin D3; $20 \mathrm{IU}$ vitamin $\mathrm{E} ; 6 \mathrm{mg}$ vitamin $\mathrm{K} ; 10 \mathrm{mg}$ vitamin B2; $35 \mathrm{mg}$ calcium pantothenate; $75 \mathrm{mg}$ niacin; $2.5 \mathrm{mg}$ vitamin B6; $0.05 \mathrm{mg}$ vitamin B12; $0.05 \mathrm{mg}$ biotin; $200 \mathrm{mg}$ choline; $150 \mathrm{mg} \mathrm{Mn} ; 500 \mathrm{mg} \mathrm{Zn}$; $40 \mathrm{mg} \mathrm{Cu}, 200 \mathrm{mg} \mathrm{Fe} ; 2 \mathrm{mg} \mathrm{I} ; 0.5 \mathrm{mg} \mathrm{Se}, 1 \mathrm{mg}$ Co.

in rats. They were fed similar amounts of feed because dry matter intake influences intestinal architecture in rats $[12,13]$ and increases endogenous protein excretion in pigs [14].

\section{MATERIALS AND METHODS}

\subsection{Animals and diets}

The experiments were conducted in agreement with the guidelines of the National University of Colombia for the care and use of laboratory animals. Ten female Wistar rats (donated by the Zoo of Cali) were blocked into pairs and randomly allocated to the casein or PF treatment. Their initial body weights were $253 \pm$ (SEM) 15 and $256 \pm 19 \mathrm{~g}$, respectively. The rats were kept in individual metabolic cages
(Tecniplast 150-300; Buguggiate, Italy) for the whole experimental period. The control diet contained $118 \mathrm{~g}$ casein $\cdot \mathrm{kg}^{-1}$ as the sole protein source, i.e. $100 \mathrm{~g}$ protein $\cdot \mathrm{kg}^{-1}$ as recommended by FAO/WHO for the determination of the nutritional value of dietary proteins in rats [15]. Casein was enriched in methionine (30 $\left.\mathrm{g} \cdot \mathrm{kg}^{-1} \mathrm{DM}\right)$ and was substituted with starch in the PF diet (Tab. I). Casein was from bovine milk (reference C7978, Sigma, St. Louis, MO, USA).

\subsection{Experimental conditions}

Daily feed allowance was set at $10 \mathrm{~g}$ in order to limit feed refusals in this study. In fact, the whole experiment comprised other diets with increasing levels of phaseolin, the bean storage globulin of Phaseolus vulgaris, and it was aimed at determining the apparent and true digestibility of this protein (Montoya C.A. et al, 2004, unpublished). Since rats offered diets with high levels of phaseolin made some feed refusals in a pre-trial, and given the fact that the level of feed intake has an impact on small intestinal architecture and enzyme activities, we decided to apply a minimal feed restriction to the rats. As a consequence, they were slightly energy-restricted ( $89 \%$ of maintenance requirements). After a period of $10 \mathrm{~d}$, the rats were fasted for the rest of the day. The following day, they received a single meal, $3 \mathrm{~h}$ before being sacrificed by asphyxia with chloroform followed by exsanguination. This post-prandial time has been considered as optimal for ileal digestibility studies in rats $[6,8]$. The rats were weighed and their abdomen was opened immediately. The digestive tract was removed, weighed and positioned on an ice-containing tray covered with a glass square. Segments including the stomach, caecum and colon were isolated and weighed filled and empty. The $\mathrm{pH}$ of the contents of the stomach and the caecum was also measured. After being unrolled and the length measured, the small intestine was divided into two halves by length, emptied and the tissues and contents were weighed. This was 
also done with the whole colon. Samples $(1.5 \mathrm{~cm}$ in length) of the small intestine were taken for histology at $10 \mathrm{~cm}$ distal from the pylorus (duodenum), in the middle of the small intestine (jejunum) and $10 \mathrm{~cm}$ before the ileo-caecal junction (ileum). Each fragment was cut longitudinally and washed with distilled water before being fixed in buffered formalin and kept at $4{ }^{\circ} \mathrm{C}$ until morphology analysis [5]. Other samples of $3 \mathrm{~cm}$ in length were collected at the same sites of the small intestine and immediately frozen in liquid nitrogen before enzyme activity determination.

\subsection{Analyses}

The diets were analysed for ash, nitrogen, ether extract and neutral detergent fibre using conventional analytical methods.

Small intestinal morphology was assessed using microdissection [16]. Villus and crypt length, width and surface area were measured using image analysis [5]. Mean values of these parameters were determined for 15 individual villi and 10 crypts from each specimen.

All the reagents used for the determination of intestinal enzyme activities were from Sigma. The frozen small intestinal samples were thawed on ice and homogenised in ice-cold saline $(\mathrm{NaCl} 0.9 \%)$ and refrozen at $-40{ }^{\circ} \mathrm{C}$ until analysis [5]. The specific activities of alkaline phosphatase (EC 3.1.3.1) and aminopeptidase N (EC 3.4.11.2.) was determined according to [17] and [18], respectively. These enzymes were retained because the former is considered a biomarker of intestinal maturation and the latter was found to vary similarly to other peptidases (aminopeptidase A and dipeptidylpeptidase IV) in young calves fed milk replacers with different protein contents [5]. Protein was measured [19] and specific enzyme activities were calculated.

\subsection{Statistical analyses}

An analysis of variance of the data was conducted using the GLM procedure of
SAS [20] in order to test the effect of the diet and, when relevant, the effects of the intestinal site and diet by site interaction. This was carried out for digesta $\mathrm{pH}$, small intestinal morphology and enzyme activities according to a split-plot design, considering block error as a residual variance to test the effect of diet and the residual error to test the effects of intestinal site and diet by site interaction. When the F-value of the analysis of variance was significant $(P<0.05)$, the means were compared by the Least Squares Difference procedure of SAS. Data are presented as means and SEM.

\section{RESULTS}

\subsection{Technical data}

The rats consumed similar amounts of casein and PF diets daily $(9.35 \pm 0.37$ and $9.46 \pm 0.17 \mathrm{~g}, P=0.64)$. This was also the case for the last meal before sacrifice where they consumed virtually all their daily allowance. The final body weight of rats did not significantly differ between the diets $(238 \pm 13$ and $224 \pm 18 \mathrm{~g}, P=0.21)$.

\subsection{Gut tissue and digesta characteristics}

The dietary treatment did not have a significant effect $(P>0.05)$ on either the tissue weight of the whole gut and its segments relative to bodyweight nor the lengths of the small intestine and colon (data not shown).

The $P F$ rats presented a $72 \%$ reduction in the weight of fresh digesta in the stomach $(P=0.045)$ (Tab. II). The weight of fresh contents in the other segments was not affected by the $\operatorname{diet}(P>0.10)$. A significant diet by site interaction was observed for the $\mathrm{pH}$ of the gut contents $(P=0.001)$. Gastric $\mathrm{pH}$ was significantly lower in the PF rats than in the casein controls $(5.33 \pm 0.20$ and $3.70 \pm 0.34, P<0.05)$ while caecal pH remained unaffected by the dietary treatment $(7.51 \pm 0.05$ and $7.69 \pm 0.08, P>0.05)$. 
Table II. Influence of the diet on the weight of fresh digesta in the gut and its segments in rats fed a casein or a protein-free diet ( $\mathrm{g} \cdot 100 \mathrm{~g}^{-1}$ bodyweight) (means and SEM, $n=5$ per treatment).

\begin{tabular}{lccc}
\hline & \multicolumn{2}{c}{ Diet $^{1}$} & $P$ \\
\cline { 2 - 4 } & Casein & PF & \\
\hline Stomach & $2.20(0.18)$ & $0.62(0.24)$ & 0.045 \\
Small intestine & $1.65(0.16)$ & $1.51(0.10)$ & 0.31 \\
Caecum & $0.61(0.06)$ & $0.82(0.12)$ & 0.11 \\
Colon & $0.41(0.12)$ & $0.27(0.08)$ & 0.24 \\
\hline
\end{tabular}

${ }^{1} \mathrm{PF}$ : protein-free diet.

Digesta $\mathrm{pH}$ was also higher in the caecum as compared to the stomach $(P<0.0001)$.

\subsection{Small intestinal architecture}

No significant diet by site interaction was observed, except for intestinal villus height to crypt depth ratio $(P=0.038)$ (Tab. III). Villus height and area were not significantly influenced by the diet $(P=0.22)$ but villus width tended to be reduced $(P=0.057)$ in the PF rats. Crypt depth, width and area were higher in the PF rats $(P=0.011, P=$ 0.004 and $P=0.001$, respectively). Small intestinal villus height to crypt depth ratio was lower in the duodenum of the PF rats as compared to the casein controls $(P<$ $0.05)$. For all the variables studied, except villus and crypt width, the effect of intestinal site was significant $(P=0.037$ to $P=0.001)$, with usually a decreasing proximo-distal gradient.

\subsection{Protein content and enzyme activities of the small intestinal mucosa}

The diet by site interaction and the diet effects for the protein content of the small intestinal mucosa were not significant $(P>$ 0.05 ) (data not shown). The diet by site interaction was significant for the specific activities of alkaline phosphatase $(P=$ $0.0006)$ and aminopeptidase $\mathrm{N}(P=0.027)$ (Tab. IV). Alkaline phosphatase activity was $36 \%$ lower in the duodenum of the PF rats $(P<0.05)$, with no significant differ- ences in the jejunum and ileum $(P>0.05)$. Aminopeptidase $\mathrm{N}$ activity was $38 \%$ lower in the duodenum and ileum, but not in the jejunum, of the PF rats $(P<0.05)$.

\section{DISCUSSION}

The major findings of the present study are deeper crypt architecture and reduced mucosal enzyme activities of the small intestine, with little effect on the villi, following chronic consumption of a proteinfree diet in rats slightly restricted in energy.

Feeding a protein-free diet has been shown to have adverse effects on the body and various organs. It decreases the rate of body protein synthesis [4] and influences body composition [21]. At the gut level, it may reduce the levels of gastric and pancreatic enzyme secretion and increase the breakdown and re-utilisation of secreted enzymes [22, 23]. The absolute amounts of amino acids transported across the intestine are decreased but the absorptive capacity (per unit of intestinal DNA) is increased [24]. In the liver, the protein synthesis is decreased [4, 25] while the activity of gammaglutamyl transpeptidase (EC 2.3.2.2.) is drastically increased [26]. An interesting transcriptomic study recently revealed that 281 genes were up- or down-regulated in the liver after feeding a protein-free diet to rats [27]. Two thirds of these genes correspond to genes already identified in receptor and signal transduction, transport and binding of proteins, amino acid metabolism 
Table III. Influence of the diet on small intestinal morphometry in rats fed a casein or a protein-free diet (means and SEM, $n=5$ per treatment).

\begin{tabular}{|c|c|c|c|c|c|c|}
\hline \multirow{2}{*}{ Variable } & \multirow{2}{*}{ Site $^{3}$} & \multicolumn{2}{|c|}{ Diet } & \multicolumn{3}{|c|}{$P^{2}$} \\
\hline & & Casein & $\mathrm{PF}$ & Diet & Site & Diet $\times$ Site \\
\hline \multirow{4}{*}{$\begin{array}{l}\text { Villus height } \\
(\mu \mathrm{m})\end{array}$} & & & & 0.22 & 0.001 & 0.13 \\
\hline & $\mathrm{D}^{\mathrm{x}}$ & $492(29)$ & $418(22)$ & & & \\
\hline & $\mathrm{J}^{\mathrm{y}}$ & 404 (12) & $410(8)$ & & & \\
\hline & $\mathrm{I}^{\mathrm{Z}}$ & $244(16)$ & 215 (18) & & & \\
\hline \multirow{4}{*}{$\begin{array}{l}\text { Villus width } \\
(\mu \mathrm{m})\end{array}$} & & & & 0.057 & 0.084 & 0.58 \\
\hline & $\mathrm{D}$ & $391(22)$ & 345 (12) & & & \\
\hline & $\mathrm{J}$ & $350(25)$ & $328(22)$ & & & \\
\hline & I & $292(17)$ & $280(21)$ & & & \\
\hline \multirow{4}{*}{$\begin{array}{l}\text { Villus area } \\
\left(\mu \mathrm{m}^{2} \times 10^{3}\right)\end{array}$} & & & & 0.22 & 0.001 & 0.21 \\
\hline & $\mathrm{D}^{\mathrm{x}}$ & $181(19)$ & $142(13)$ & & & \\
\hline & $\mathrm{J}^{\mathrm{y}}$ & $135(12)$ & $129(11)$ & & & \\
\hline & $\mathrm{I}^{\mathrm{Z}}$ & $68(5)$ & $62(8)$ & & & \\
\hline \multirow{4}{*}{$\begin{array}{l}\text { Crypt depth } \\
(\mu \mathrm{m})\end{array}$} & & & & 0.011 & 0.016 & 0.31 \\
\hline & $\mathrm{D}^{\mathrm{x}}$ & $164(11)$ & $200(9)$ & & & \\
\hline & $\mathrm{J}^{\mathrm{y}}$ & $154(7)$ & $181(6)$ & & & \\
\hline & $\mathrm{I}^{\mathrm{Z}}$ & $150(5)$ & $161(7)$ & & & \\
\hline \multirow{4}{*}{$\begin{array}{l}\text { Crypt width } \\
(\mu \mathrm{m})\end{array}$} & & & & 0.004 & 0.19 & 0.20 \\
\hline & D & $40(4.5)$ & $45(2.5)$ & & & \\
\hline & $\mathrm{J}$ & $30(1.8)$ & 45 (1.6) & & & \\
\hline & I & $35(2.2)$ & $47(2.0)$ & & & \\
\hline \multirow{4}{*}{$\begin{array}{l}\text { Crypt area } \\
\left(\mu \mathrm{m}^{2} \times 10^{3}\right)\end{array}$} & & & & 0.001 & 0.037 & 0.30 \\
\hline & $\mathrm{D}^{\mathrm{x}}$ & $5.0(0.25)$ & $8.2(0.36)$ & & & \\
\hline & $\mathrm{J}^{\mathrm{y}}$ & $4.0(0.35)$ & $7.1(0.33)$ & & & \\
\hline & $\mathrm{I}^{\mathrm{Z}}$ & $4.5(0.37)$ & $6.4(0.47)$ & & & \\
\hline \multicolumn{4}{|c|}{ Villus height to crypt depth ratio } & 0.021 & 0.001 & 0.038 \\
\hline & $\mathrm{D}$ & $3.1^{\mathrm{a}}(0.24)$ & $2.1^{\mathrm{bcd}}(0.12)$ & & & \\
\hline & $\mathrm{J}$ & $2.7^{\mathrm{ab}}(0.14)$ & $2.3^{\mathrm{abc}}(0.15)$ & & & \\
\hline & I & $1.6^{\mathrm{cd}}(0.08)$ & $1.3^{\mathrm{d}}(0.06)$ & & & \\
\hline
\end{tabular}

${ }_{1}^{1} \mathrm{PF}$ protein-free diet.

${ }^{2}$ Means with different superscripts for a given variable (a, b, c, d) or site (x, y, z) differ $(P<0.05)$.

${ }^{3} \mathrm{D}$ : duodenum, J: jejunum, I: ileum. 
Table IV. Influence of the diet on small intestinal enzyme activities in rats fed a casein or a proteinfree diet (means and SEM, $n=5$ per treatment).

\begin{tabular}{|c|c|c|c|c|c|c|}
\hline \multirow{2}{*}{ Variable } & \multirow{2}{*}{ Site $^{3}$} & \multicolumn{2}{|c|}{ Diet } & \multicolumn{3}{|c|}{$P^{2}$} \\
\hline & & Casein & $\mathrm{PF}$ & Diet & Site & Diet $\times$ Site \\
\hline \multirow[t]{4}{*}{ Alkaline phosphatase ${ }^{4}$} & & & & 0.027 & 0.001 & 0.001 \\
\hline & $\mathrm{D}$ & $411^{\mathrm{a}}(26)$ & $264^{\mathrm{b}}(24)$ & & & \\
\hline & $\mathrm{J}$ & $68^{c}(13)$ & $81^{\mathrm{c}}(19)$ & & & \\
\hline & I & $44^{\mathrm{c}}(17)$ & $41^{\mathrm{c}}(12)$ & & & \\
\hline \multirow[t]{4}{*}{ Aminopeptidase $\mathrm{N}^{5}$} & & & & 0.013 & 0.001 & 0.027 \\
\hline & $\mathrm{D}$ & $38^{\mathrm{ab}}(6)$ & $24^{c}(4)$ & & & \\
\hline & $\mathrm{J}$ & $51^{\mathrm{ab}}(2)$ & $48^{\mathrm{ab}}(4)$ & & & \\
\hline & I & $55^{\mathrm{a}}(5)$ & $34^{\mathrm{bc}}(5)$ & & & \\
\hline
\end{tabular}

${ }^{1} \mathrm{PF}$ protein-free diet.

2 Means with different superscripts for a given variable $(a, b, c)$ differ $(P<0.05)$.

3 D: duodenum, $\mathrm{J}$ : jejunum, I: ileum.

${ }^{4} \mathrm{nmol}$ substrate degraded/mg tissue protein $/ \mathrm{h}$.

$5 \mu \mathrm{mol}$ substrate degraded $/ \mathrm{mg}$ tissue protein $/ \mathrm{h}$.

and gene expression control, etc. One third of the genes were unassigned to particular molecules or functions, suggesting the consequences of protein deprivation to be much broader than anticipated. The effects of a protein-free diet are also reflected in the plasma. The levels and/or molar ratios of all indispensable amino acids and plasma proteins, including albumin, are decreased while those of several gluconeogenetic amino acids, especially glycine and alanine, and gamma glutamyl transpeptidase activity are all increased [26, 28]. Finally, protein synthesis and the levels of most amino acids were also decreased in the brain of rats fed a protein-free diet [29].

Here, rats consuming a PF diet had a lower gastric $\mathrm{pH}$ and accelerated emptying rate, probably due to the absence of casein and clotting in this compartment. Intestinal CCPR is under hormonal control through gastrin action [30-32]. Whether the crypt morphology changes observed here were influenced by changes in plasma gastrin levels is not known because we did not measure it in the present study.

Villus height was little affected by the dietary treatment here. This is in sharp contrast with our previous observations with preruminant calves fed milk replacers varying in protein content [5]. Villus height and width and crypt width and area were reduced by 20 to $30 \%$ in various parts of the small intestine with the PF diet. Milk replacers for calves contain high levels of lactose and fat, combined with low levels of starch and no fibre. These highly digestible diets, when they are protein free, are most probably completely digested in the proximal small intestine [5], with a resulting median to distal villus-crypt atrophy, as seen in models of total parenteral nutrition [33, 34]. Here, the experimental diets contained fibre and starch. This might have provided the minimal energy and load necessary for restoring intestinal atrophy observed in rats on total parenteral nutrition [34]. Studies with neonatal pigs have also shown that the minimal enteral nutrient intake necessary to increase mucosal mass is close to $40 \%$ of total nutrient intake [35].

The present enzyme activity results are in good agreement with published data showing reduced specific activities of alkaline phosphatase and aminopeptidase $\mathrm{N}$ in rats $[9,13,36]$ and calves [5] fed diets low in protein. An influence of the amount of 
starch, which was $20 \%$ higher in the PF diet, on enzyme activities cannot be excluded. However, increasing the protein level in a diet is often achieved at the expense of starch, thus leading to confounded effects. For example, diets with low starch and high casein contents result in higher specific activity of leucine-aminopeptidase than diets with high starch and low casein contents [37]. Intestinal alkaline phosphatase activity (but not that of maltase) has been found to be higher in rats fed a starch, as compared to sucrose, diet [38]. Here, the lack of difference in caecal $\mathrm{pH}$ between treatments only suggests that the differences in diet, and therefore starch composition did not significantly influence this factor.

In conclusion, feeding a PF diet to rats slightly restricted in energy affected gastric emptying and small intestinal mucosal architecture and enzyme activities. Our data support the view that dietary protein is stimulatory to intestinal mucosa [39] and endogenous protein secretion $[7,8]$.

\section{ACKNOWLEDGEMENTS}

Thanks are due to COLCIENCIAS (Bogotá, Colombia), ECOS-Nord (Université Paris 5, France) and the Volkswagen foundation (Hannover, Germany) for financial support. The authors also thank Professor J.E. Muñoz for statistical advice, Mr. J.C. Henao and the technical staff in Palmira, Colombia, and Rennes, France, for help in this work.

\section{REFERENCES}

[1] Sève B, Henry Y. Protein utilization in nonruminants. In: Nunes AF, Portugal AV, Costa JP, Ribeiro JR (Eds), Proceedings of the 7th symposium on protein metabolism and nutrition, Santarém, EAAP publication No. 81, 1996, p 59-82.

[2] Nyachoti CM, de Lange CFM, McBride BW, Schulze H. Significance of endogenous gut nitrogen losses in the nutrition of growing pigs: a review. Can J Anim Sci 1997, 77: 149-163.

[3] Low AG. Nutrient absorption in pigs. J Sci Food Agric 1980, 31: 1087-1130.
[4] Millward DJ, Garlick PJ, James WPT, Sender P, Withelow JC. Protein turnover. In: Cole DJA, Boorman KN, Buttery PJ, Lewis D, Neale RJ, Swan H. (Eds), Protein metabolism and nutrition, Butterworths Co Ltd, London, UK, 1976, p 49-69.

[5] Lallès JP, Montagne L, Plut C, Toullec R. Influence of dietary protein concentration on the morphology and enzyme activities of the small intestine of the pre-ruminant calf. Anim Sci 2001, 73: 571-578.

[6] Skilton GA, Moughan PJ, Smith WC. Determination of endogenous amino acid flow at the terminal ileum of rats. J Sci Food Agric 1988, 44: 227-235.

[7] Butts CA, Moughan PJ, Smith WC. Endogenous amino acid flow at the terminal ileum of the rat determined under conditions of peptide alimentation. J Sci Food Agric 1991, 55: 175-187.

[8] Donkoh A, Moughan PJ, Morel PCH. Comparison of methods to determine the endogenous amino acid flow at the terminal ileum of the growing rat. J Sci Food Agric 1995, 67: 359-366.

[9] Guiraldes E, Hamilton JR. Effect of chronic malnutrition on intestinal structure, epithelial renewal, and enzymes in suckling rats. Pediatr Res 1981, 15: 930-934.

[10] Goodlad RA, Wright NA. The effect of starvation and refeeding on intestinal cell proliferation in the mouse. Virchows Arch B 1984, 45: 63-73.

[11] Waheed AA, Gupta PD. Changes in structural and functional properties of rat intestinal brush border membrane during starvation. Life Sci 1997, 61: 2425-2433.

[12] Goodlad RA, Plumb JA, Wright NA. The relationship between intestinal crypt cell production and intestinal water absorption measured in vitro in the rat. Clin Sci (London) 1987, 72: 297-304.

[13] Zambonino-Infante JL, Rouanet JM, Caporiccio $\mathrm{B}$, Besançon P. Effects of dietary protein and carbohydrate level in the rat small intestine: enzymic, histological and electron microscopy studies. Nutr Rep Int 1989, 40: 313-321.

[14] Butts CA, Moughan PJ, Smith WC, Reynolds $\mathrm{GW}$, Garrick DJ. The effect of food dry matter intake on endogenous ileal amino acid excretion determined under peptide alimentation in the $50 \mathrm{~kg}$ liveweight pig. J Sci Food Agric 1993, 62: 235-243.

[15] Gilani G, Sepehr E. Protein digestibility and quality in products containing antinutritional 
factors are adversely affected by old age in rats. J Nutr 2003, 133: 220-225.

[16] Goodlad RA, Levi S, Lee CY, Mandir N, Hodgson H, Wright NA. Morphometry and cell proliferation of endoscopic biopsies: evaluation of a technique. Gastroenterology 1991, 101: 1235-1241.

[17] Martins MJ, Negrao MR, Hipolito-Reis C, Azevedo I. Physiologic concentrations of bile salts inhibit rat hepatic alkaline phosphatase but not the intestinal isoenzyme. Clin Biochem 2000, 33: 611-617.

[18] Sangild PT, Sojstrom H, Noren O, Fowden AC, Silver M. The prenatal development and glucocorticoid control of brush border hydrolases in the pig small intestine. Pediatr Res 1995, 37: 207-212.

[19] Lowry OH, Rosebrough NJ, Farr AL, Randall RJ. Protein measurement with the Folin phenol reagent. J Biol Chem 1951, 193: 265-275.

[20] SAS. User's guide: statistics, version 8.0 edition. SAS Institute Inc. Cary, NC, 1999.

[21] Chang YO, Soong CC. Effect of feeding diets lacking various essential amino acids on body composition of rats. Int J Vitam Nutr Res 1975, 45: 230-236.

[22] Fauconneau G, Michel MC. In: Munro HN, Allison JB (Eds), Mammalian protein metabolism, Academic Press, New York, 1970, Vol 4, p 481-522.

[23] Schneeman BO. In : Laplace JP, Corring T, Rerat A (Eds), Physiologie digestive chez le porc, Colloques de l'INRA n ${ }^{\circ} 12$, INRA Paris, 1982, p 125-131.

[24] Kansal VK, Wahie I. Intestinal transport of amino acids in protein-deficient rats and the effect of rehabilitation using a casein diet. J Nutr 1981, 111: 1513-1521.

[25] Sato A, Noda K, Natori Y. The effect of protein depletion on the rate of protein synthesis in rat liver. Biochim Biophys Acta 1979, 561: 475-483.

[26] De Oliveira IM, de Angelis RC. Differential effects of protein restriction on gammaglutamyl transpeptidase [EC 2.3.2.2] activity in young and mature rats. Braz J Med Biol Res 1996, 29: 213-217.

[27] Kato H, Kimura T. Evaluation of the effects of the dietary intake of proteins and amino acids by DNA microarray technology. J Nutr 2003, 133: 2073S-2077S.

[28] Suzic R, Radunovic L, Jankovic V, Segovic R Effects of protein-free diet in amino acid homeostasis of rat blood plasma and gut contents. FEBS Lett 1987, 216: 287-290.

[29] Yokogoshi H, Hayase K, Yoshida A. The quality and quantity of dietary protein affect brain protein synthesis in rats. J Nutr, 1992, 122: 2210-2217.

[30] Goodlad RA, Al-Mukhtar MY, Ghatei MA, Bloom SR, Wright NA. Cell proliferation, plasma enteroglucagon and plasma gastrin levels in starved and refed rats. Virchows Arch B 1987, 43: 55-62.

[31] Goodlad RA, Ratcliffe B, Fordham JP, Wright NA. Does dietary fibre stimulate epithelial cell proliferation in germ free rats? Gut 1989, 30: 820-825.

[32] Ekundayo AA, Lee CY, Goodlad RA. Gastrin and the growth of the gastrointestinal tract. Gut 1995, 36: 203-208.

[33] McCauley RD, Heel KA, Christiansen KJ, Hall JC. The effect of minimum luminal nutrition on bacterial translocation and atrophy of the jejunum during parenteral nutrition. J Gastroenterol Hepatol 1996, 11: 65-70.

[34] Ohta K, Omura K, Hirano K, Kanehira E, Ishikawa N, Kato Y, Kawakami K, Watanabe $\mathrm{G}$. The effects of an additive small amount of a low residual diet against total parenteral nutrition-induced gut mucosal barrier. Am J Surgery 2003, 185: 79-85.

[35] Burrin DG, Stoll B, Jiang R, Chang X, Hartmann B, Holst JJ, Greeley GH, Reeds PJ. Minimal enteral nutrient requirements for intestinal growth in neonatal piglets: how much is enough? Am J Clin Nutr 2000, 71: 1603-1610.

[36] Raul F, Goda T, Gosse F, Koldovsky O. Shortterm effect of a high protein/low carbohydrate diet on aminopeptidase in adult rat jejunum. Biochem J 1987, 247: 401-407.

[37] Saito M, Suda M. Effect of diet on enzymes of the brush border of the small intestine and kidney of rats. J Nutr Sci Vitaminol 1975, 21, 207-215.

[38] Wiesenfeld P, Baldwin J, Szepesi B, Michaelis OE. Effect of dietary carbohydrate and phenotype on sucrase, maltase, lactase, and alkaline phosphatase specific activity in SHR/N-cp rat. Proc Soc Exp Biol Med 1993, 202: 338-344.

[39] Poullain MG, Cezard JP, Marche C, Roger L, Mendy F, Broyart JP. Dietary whey proteins and their peptides or amino acids: effects on the jejunal mucosa of starved rats. Am J Clin Nutr 1989, 49: 71-76. 